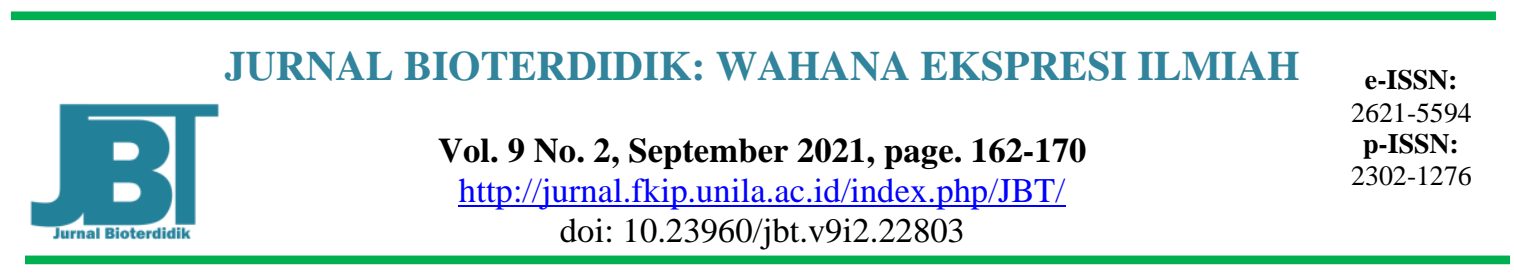

\title{
Pengembangan $e$-Modul Bryophyta Dengan Kajian Islam Sebagai Alternatif Bahan Ajar Di Era New Normal
}

\author{
Linda Amalia Saragih, Indayana Febriani Tanjung, Efrida Pima Sari Tambunan \\ Universitas Islam Negeri Sumatera Utara \\ *email: liasaragih6@gmail.com
}

Received: August 23, 2021

Accepted: September 25, 2021

Online Published: September 30, 2021

\begin{abstract}
Development of the Bryophyta e-Module with Islamic Studies as an Alternative Teaching Material in the New Normal Era. This study aims to develop additional teaching materials in the form of e-Modul Bryophyta dengan Kajian Islam, as well as to determine the quality of the products developed based on the assessment of several validations, teachers, and students as respondents. The data collection instrument used a questionnaire. Descriptive qualitative and quantitative data analysis. The results of the research obtained indicate that the Bryophyta e-Module with Islamic Studies developed as a whole has the quality Very Fit for use in teaching and learning activities. With the percentage results from material experts of $89.2 \%$ with Very Feasible criteria, from media experts of $71.6 \%$ with Eligible criteria, from Islamic Religion experts of $82.6 \%$ with Very Appropriate criteria and an assessment of the teacher of $82.5 \%$ with criteria Very Eligible for use in teaching and learning activities. Meanwhile, the response of students obtained the overall percentage of small and large group tests of $85.2 \%$ with very attractive criteria. Thus, it can be concluded that e-Modul Bryophyta dengan Kajian Islam, which was developed with the Borg \& Gall model, is feasible and very attractive to be used as teaching material for students in class X MIA in Ma, especially in Bryophyta lessons.
\end{abstract}

Keywords: biology, Bryophyta e-Module, teaching materials development

Abstrak: Pengembangan e-Modul Bryophyta Dengan Kajian Islam Sebagai Alternatif Bahan Ajar Di Era New Normal. Penelitian ini bertujuan untuk mengembangkan bahan ajar tambahan berupa e-Modul Bryophyta dengan Kajian Islam serta mengetahui kualitas produk yang dikembangkan berdasarkan penilaian dari beberapa validasi, guru dan peserta didik sebagai responden. Instrumen pengambilan data menggunakan angket. Analisis data secara deskriptif kualitatif dan kuantitatif. Hasil penelitian yang diperoleh menunjukkan bahwa $e$ Modul Bryophyta dengan Kajian Islam yang dikembangkan secara keseluruhan memiliki kualitas Sangat Layak untuk digunakan didalam kegiatan belajar mengajar. Dengan hasil persentase dari ahli materi sebesar 89,2\% dengan kriteria Sangat Layak, dari ahli media sebesar 71,6 \% dengan kriteria Layak, dari ahli Agama Islam sebesar 82,6\% dengan kriteria Sangat Layak dan penilaian dari guru sebesar $82,5 \%$ dengan kriteria Sangat Layak untuk digunakan didalam kegiatan belajar mengajar. Sementara itu, respon peserta didik diperoleh persentase keseluruhan uji kelompok kecil dan kelompok besar sebesar 85,2 \% dengan kriteria Sangat Menarik. Dengan demikian, dapat disimpulkan bahwa $e$-Modul Bryophyta dengan Kajian Islam yang dikembangkan dengan model Borg \& Gall, Layak dan Sangat Menarik untuk digunakan sebagai bahan ajar bagi siswa di kelas X MA, khususnya pada materi Bryophyta.

Kata kunci: biologi, e-Modul Bryophyta, pengembangan bahan ajar 


\section{PENDAHULUAN}

Berdasarkan data yang diambil dari Survei Political and Economic Risk Consultan (PERC) pada tahun 2018 bahwa kualitas pendidikan di Indonesia berada pada urutan 14 dari 16 negara di Asia. Survei ini dilakukan pada tahun 2018. Melihat survei ini, Indonesia memiliki angka yang rendah dalam mutu pendidikan. Rendahnya mutu pendidikan di Indonesia disebabkan oleh rendahnya efektivitas, efisiensi, standarisasi guru dalam mengajar dan kurang kreatifnya para guru dalam memberi pembelajaran bagi peserta didik serta kurikulum yang didasari pada pengetahuan pemerintah tanpa memperhatikan kebutuhan masyarakat Indonesia. Hal ini menyebabkan peserta didik dituntut untuk menyelesaikan pembelajaran yang telah ditetapkan pemerintah didalam kurikulum tanpa melihat minat dan ketertarikan peserta didik sehingga beberapa peserta didik kesulitan untuk mengikuti kegiatan belajar mengajar.

Selain itu, dilihat dari janji Allah SWT dalam al-Qur'an untuk memberi derajat yang tinggi bagi orang-orang yang berilmu dan berpendidikan, seperti tercermin dalam Q.S Mujadilah ayat-11:

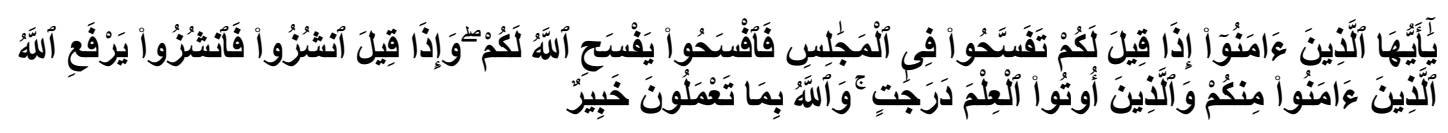

Artinya: "Hai orang-orang beriman apabila dikatakan kepadamu: "Berlapanglapanglah dalam majelis", maka lapangkanlah niscaya Allah SWT akan memberi kelapangan untukmu. Dan apabila dikatakan: "Berdirilah kamu", maka berdirilah, niscaya Allah SWT akan meninggikan orang-orang yang beriman diantaramu dan orang-orang yang diberi ilmu pengetahuan beberapa derajat. Dan Allah Maha Mengetahui apa yang kamu kerjakan."

Dan sebagaimana sabda Nabi Muhammad SAW:

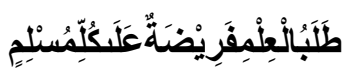

Artinya: "Menuntut ilmu itu wajib atas setiap muslim"

Dalam ayat dan hadist diatas memberikan petunjuk bahwa di dalam Islam, sebuah ilmu sangat dijunjung tinggi. Manusia diwajibkan untuk menuntut ilmu guna bekal kehidupannya di dunia. Seperti yang tercermin dalam ayat dan hadist Rasulullah SAW diatas. (Susan, 2016)

Pada akhir tahun 2019, muncul pandemi yang memberikan pengaruh cukup besar pada berbagai aspek kehidupan salah satunya aspek pendidikan. Pandemi ini telah menyerang berbagai negara, yang dikenal dengan nama Covid-19 (Corona Virus Disease 2019). Pandemi ini pertama kali muncul di Wuhan, China, dan telah menimbulkan banyak korban karena penyebaran dan penularannya yang cukup ganas. WHO (World health Organization atau Badan Kesehatan Dunia) secara resmi mendeklarasikan Virus Corona (Covid-19) sebagai pandemi pada tanggal 9 Maret 2020. Artinya Virus Corona telah menyebar secara luas di dunia.

Pada awal tahun 2020, tepatnya pada akhir bulan Februari, penyebaran Covid-19 telah sampai ke Indonesia. Pada awal Maret, pemerintah Indonesia dengan sigap menetapkan keadaan darurat Covid-19 dan mengeluarkan kebijakan protokol kesehatan dan perlindungan diri guna menekan penyebaran wabah Virus Corona di Indonesia. Hal ini mempengaruhi dunia pendidikan untuk menyesuaikan proses pembelajaran sesuai dengan protokol kesehatan dan perlindungan diri yang telah ditetapkan pemerintah. 
Dengan situasi tersebut, pemerintah menetapkan bahwasanya proses pembelajaran baik di sekolah maupun universitas diselenggarakan dari rumah dengan sistem daring atau online. Kebijakan pemerintah yang merupakan physical distancing adalah upaya untuk menjaga jarak antara satu sama lain guna memutus penyebaran Virus Corona. Untuk menyelaraskan kebijakan tersebut, pemerintah membuat sistem pendidikan secara online menggunakan jaringan internet.

Pembelajaran secara daring/ online sebelumnya telah dikenalkan di dunia pendidikan seiring dengan perkembangan teknologi. Namun pembelajaran online tidak bisa menjadi option yang bagus dikarenakan tujuan pembelajaran yang dirasa kurang tercapai apabila pembelajaran online di terapkan. Dizaman yang serba teknologi seperti sekarang, peserta didik dan guru juga dituntut untuk memanfaatkan teknologi dalam pembelajaran. Ditambah pada masa pandemi ini, dalam pembelajaran online yang berlangsung sangat membutuhkan sumber belajar agar pembelajaran tetap berjalan seperti semestinya dan mencapai tujuan pembelajaran. Maka dari itu dibutuhkannya media pembelajaran tambahan sebagai dukungan bahan ajar dalam pembelajaran online di era new normal dimasa pandemi Covid-19.

Dari hasil wawancara yang telah peneliti lakukan dengan guru Biologi di MA AlJamiyatul Wasliyah Tanjungbalai, bahwa saat itu bahan ajar yang digunakan siswa/i dalam kegiatan belajar mengajar adalah buku LKS yang diberikan kepada siswa/i, sedangkan buku BIOLOGI K13 hanya diterima oleh guru biadang studi saja karena jumlahnya yang masih sangat terbatas disekolah tersebut. Hal ini menyebabkan beberapa guru mencari beberapa bahan ajar tambahan dari internet untuk diajarkannya kepada siswa. Maka berdasarkan hasil wawancara tersebut, peneliti melakukan pengembangan sebuah bahan ajar dengan mengangkat materi Bryophyta, karena materi Bryophyta lah yang menurut guru Biologi di Ma Al-Jamiyatul Wasliyah Tanjungbalai sulit untuk ditemukan di internet.

Berdasarkan fakta diatas maka peneliti tertarik untuk melakukan pengembangan bahan ajar berupa e-Modul Bryophyta dengan Kajian Islam. e-Modul Bryophyta dengan Kajian Islam ini dibuat bertujuan sebagai alternatif bahan ajar yang akan digunakan oleh peserta didik dalam pembelajaran Online. Peserta didik diharapkan dapat melakukan kegiatan belajar dengan mandiri atas panduan dari modul. e-Modul Bryophyta dengan Kajian Islam ini juga diharapkan dapat digunakan sebagai sumber belajar tambahan dalam pembelajaran Biologi dengan konten Islam sebagai kontrol dalam mempelajari Biologi sehingga memudahkan peserta didik belajar ilmu pengetahuan dengan menghubungkannya dengan ilmu Islam.

Rumusan masalah dari penelitian ini yaitu bagaimana cara pengemabangan e-Modul Bryophyta dengan Kajian Islam serta bagaimana kelayakan e-Modul Bryophyta dengan Kajian Islam sebagai alternatif bahan ajar di era new normal. Tujuan dari penelitian ini yaitu untuk mengetahui cara pengembangan e-Modul Bryophyta dengan Kajian Islam serta untuk mengetahui kelayakan e-Modul Bryophyta dengan Kajian Islam sebagai alternatif bahan ajar di era new normal.

\section{METODE}

Penelitian ini menggunakan metode penelitian dan pengembangan atau Research and Development $(R \& D)$, dimana penelitian ini dilakukan untuk menghasilkan produk tertentu dan menguji keefektifan produk yang akan dikembangkan. (Sugiyono, 2018). 
Produk yang dikembangkan adalah e-Modul Bryophyta dengan Kajian Islam. Subjek penelitian ini yaitu siswa/i kelas X SMA/MA. Pengembangan dilaksanakan pada mata pelajaran Biologi, tahun ajaran 2020/2021.

Model penelitian yang digunakan adalah model Borg and Gall yang dimodifikasi oleh Sugiyono (2018), dimana model ini meliputi beberapa tahap yaitu: Potensi dan Masalah, Pengumpulan Data, Desain Produk, Validasi Desain, Revisi Desain, Uji Coba Produk, Revisi Produk.

e-Modul Bryophyta dengan Kajian Islam diuji kelayakannya oleh 6 orang pakar yang terdiri dari 3 orang dosen UIN SU Medan, dan 3 orang guru Biologi. Uji kelayakan tersebut meliputi uji materi, uji media dan uji Agama Islam, sedangkan 3 orang guru menguji kelayakan dan kemenarikan materi e-Modul Bryophyta dengan Kajian Islam dari sudut pandang pendidik. Selanjutnya e-Modul Bryophyta dengan Kajian Islam di uji kemenarikan oleh siswa pada uji skala kecil dan penggunaannya pada uji skala besar.

\section{HASIL DAN PEMBAHASAN}

Pengembangan e-Modul Bryophyta dengan Kajian Islam bertujuan agar mampu membantu dan mendorong peserta didik dalam meningkatkan pengetahuan serta memperoleh kemudahan dalam memahami pelajaran Bryophyta dengan kajian Islam.

Hubungan antara Islam dengan ilmu sains menggunakan pendekatan inter-disipliner, dimana pendekatan ini dilakukan dengan memasukkan ayat-ayat Al-Qur'an ke dalam pokok bahasan untuk memperdalam dan memperkuat makna pemahaman yang dihasilkan. (Faiz,2014). Upaya yang dilakukan dalam menghubungkan ilmu Sains dan ilmu Islam untuk membangun keilmuan yang dilandasi dengan keimanan dan ketaqwaan. Dengan melihat hal tersebut, diharapkan terjadi hubungan emosial yang kuat antara obyek bahasan, peserta didik dan nilai-nilai Islam. (Nurhadi,2017). Permasalahan yang sering dihadapi oleh masyarakat pendidikan saat ini adalah karena adanya perbedaan antara kedua ilmu tersebut maka kurangnya bahan ajar yang menggabungkan ilmu Sains dengan ilmu keislaman. Modul pembelajaran yang ada di Madrasah harus berbeda dengan yang ada di sekolah umum, modul pembelajaran yang ada di Madrasah tersebut harus bernuansa islami agar tujuan belajar di Madrasah terwujud sesuai dengan yang diinginkan pada Kurikulum Madrasah serta memberikan siswa/i yang kepribadian Islami. Oleh karena itu, materi yang dibawakan oleh e-Modul Bryophyta dengan Kajian Islam ini menghubungkan materi Bryophyta dengan ayat-ayat Al-Qur'an yang dapat memperdalam dan memperkuat pemahaman peserta didik dari segi ilmu Sains dan ilmu Islam.

Terdapat 7 dari 10 tahapan pengembangan yang dilakukan didalam penelitian dan pengembangan produk e-Modul Bryophyta dengan Kajian Islam ini, dimana penelitian dan pengembangan ini menggunakan teknik yang dikemukakan oleg Borg \& Gall yang meliputi diantaranya: (1) Potensi dan Masalah, (2) Pengumpulan Data, (3) Desain Produk, (4) Validasi Desain, (5) Revisi Desain, (6) Uji Coba Produk, (7) Revisi Produk. Pengembangan dibatasi menjadi 7 langkah dari 10 langkah penelitian, hal ini sejalan dengan pendapat yang diungkapakan oleh Ardhana. Ardhana mengungkapkan, setiap pengembang dapat memilih dan menentukan langkah yang paling sesuai dengan kondisi khusus yang dihadapinya dalam proses pengembangan. (Sugiyono,2015). Oleh karena 
itu, karena peneliti hanya melihat kelayakan produk berdasarkan evaluasi validator, evaluasi guru biologi, dan evaluasi siswa berdasarkan daya tariknya, maka penelitian ini belum sampai pada tahap Publish dan Produksi produk.

Pengembangan diawali dengan menemukan potensi dan masalah yang ada di lapangan. Hal ini peneliti lakukan di Madrasah Aliyah Al-Jamiyatul Wasliyah Tanjungbalai. Untuk melihat keadaan pembelajaran pada mata pelajaran biologi yang ada di sekolah. Hasil dari menemukan potensi dan masalah yang ada di sekolah, peneliti menemukan bahwa sekolah menggunakan buku LKS yang diberikan kepada peserta didik untuk dijadikan sumber belajar, dan untuk guru sudah memiliki buku paket K13 yang digunakan sebagai bahan ajar. Di dalam pembelejaran, beberapa guru juga sudah menggunakan media pembelajaran, seperti infocus yang menampilkan video pembelajaran dan PPT yang telah disiapkan oleh guru. Namun setelah Covid-19, sekolah melakukan pembelajaran secara online. Hal ini mengakibatkan guru kesulitan untuk berkomunikasi secara leluasa dengan peserta didik. Dikarenakan buku yang digunakan guru yaitu buku paket biologi K13 tidak dimiliki oleh peserta didik di sekolah tersebut. Setelah mendapatkan informasi, informasi tersebut akan dikumpulkan dan yang dapat digunakan sebagai bahan perencanaan agar kegiatan pengembangan dan penelitian dapat berjalan dengan lancar dalam pengembangan produk. hal yang harus diingat adalah untuk mencatat perkiraan biaya dan waktu yang dibutuhkan untuk penelitian dan pengembangan.

Langkah selanjutnya dilakukan pengembangan desain produk e-Modul Bryophyta dengan Kajian Islam. Setelah desain produk selesai, selanjutnya dilakukan proses validasi untuk mengetahui kelayakan/ kevalidan produk yang dikembangkan menurut pada ahi yaitu ahli materi, ahli media dan ahli Agama Islam permasing-masing ahli menggunakan 1 orang dosen UIN SU yang ahli pada bidangnya.

Berdasarkan hasil validasi yang telah dilakukan oleh validator ahli materi memperoleh hasil awal sebesar 75 dari skor maksimal 112 dan persentasenya 66,9\% dengan kategori layak diuji coba namun dengan beberapa revisi. Setelah di revisi dan validasi ulang, produk memperoleh hasil validasi akhir sebesar 100 dari skor maksimal 112 , persentase $89,2 \%$ dengan kategori sngat layak digunakan.

e-Modul Bryophyta dengan Kajian Islam setelah revisi ini terdiri beberapa Bab, dimana Bab 1 terdiri dari pendahuluan, deskripsi singkat tentang modul, standar kompetensi, peta konsep, manfaat modul, tujuan pembelajaran, petunjuk penggunaan modul. Pada Bab 2 yaitu Materi belajar: Bryophyta yang berisi materi-materi pembelajaran mengenai Bryophyta, rangkuman materi, latihan siswa, tes mandiri, dan tes diskusi. Di Bab 3 yaitu evaluasi, maksud dan tujuan evaluasi, materi yang akan dievaluasi, soal evaluasi, dan lembar kerja siswa (LKS). Pada Bab terakhir yaitu Bab IV Penutup terdiri dari tindak lanjut dan harapan penulis untuk kedepannya. Kemudian terdapat glosarium atau kata-kata penting dalam materi yang diberikan, dan juga pada bebrapa halaman penulis menambahkan section "did you know?" dan "Motivation" sebagai ikon pengingat dan motivasi untuk peserta didik dalam kegiatan belajar. Disetiap akhir materi di sajikan "Quiz!" sebagai pengukur kemampuan siswa dalam mempelajari setiap satu meteri yang disajikan e-Modul Bryophyta dengan Kajian Islam. Serta adanya animasi menarik sehingga peserta didik tidak bosan pada waktu pembelajaran berlangsung. Bagian terakhir dari modul ini adalah daftar pustaka sebagai 
daftar buku yang digunakan sebagai referensi penulidan e-Modul Bryophyta dengan Kajian Islam.

Sesuai dengan yang dikemukakan Lasmiyati (2014) yang menyatakan bahwa untuk penggunaan bahasa yang sederhana membuat modul mudah dipahami, serta dapat meningkatkan pemahaman konsep dan minat belajar siswa. Pada prinsip penyajian menurut Sungkono dalam Purwaning (2017) yaitu harus memenuhi beberapa persyaratan, yaitu (1) materi harus terkait dengan sifat kompetensi; (2) materi berada dalam lingkup tema inti; (3) pengungkapan materi logis, sistematis, dan komunikatif/ Interaktif dan tidak kaku, (4) Memperhatikan latar belakang / lingkungan peserta didik.

Berdasarkan hasil validasi yang telah dilakukan oleh validator ahli media, diperoleh hasil awal sebesar 37 dari skor maksimal 60 dengan persentase 61,6\% masuk kategori layak namun dengan beberapa revisi. Setelah revisi, produk memperoleh hasil akhir sebesar 43 dari skor maksimal yaitu 60 dengan persentase 71,6\% yang artinya modul ini masuk dalam kategori Layak/Valid untuk digunakan di dalam pembelajaran biologi. Adapun desain produk e-Modul Bryophyta dengan Kajian Islam ini, diantaranya adalah menyesuaikan standar kompetensi dan kompetensi dasar serta RPP berdasarkan Kurikulum 2013.

Sesuai dengan yang dikemukakan oleh Lestari (2013) bahwa grafis modul dinilai dari desain layout, layout, gambar, desain tampilan, dan ukuran huruf yang jelas dan menarik secara keseluruhan, sehingga dapat merangsang minat siswa terhadap bahan bacaan

Berdasarkan hasil validasi yang telah dilakukan oleh validator ahli Agama Islam memperoleh hasil awal sebesar 36 dari skor maksimal 52 dengan persentase 69,2\% masuk kategori layak namun dengan beberapa revisi. Setelah produk di revisi dan dilakukan validasi ulang, produk memperoleh hasil akhir sebesar 43 dengan skor maksimal 52 dengan persentase $82,6 \%$ yang artinya modul ini masuk dalam kategori Sangat Layak/ Sangat Valid untuk digunakan didalam pembelajaran Biologi. Ditinjau dari kriteria kevalidan dari ahli materi, ahli media, dan ahli Agama Islam, maka produk e-Modul Bryophyta dengan Kajian Islam ini telah memiliki kriteria validitas yang valid/layak digunakan sebagai bahan ajar di pembelajaran biologi.

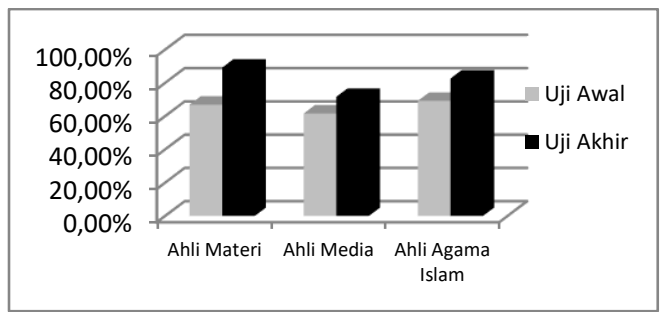

Gambar 1. Hasil Uji Awal dan Akhir dari Ahli Materi, Ahli Media dan Ahli Agama Islam

Selain para ahli, produk e-Modul Bryophyta dengan Kajian Islam ini juga dinilai oleh peserta didik dan guru di Madrasah Aliyah Al-Jamiyatul Wasliyah Tanjungbalai. Penilaian produk e-Modul Bryophyta dengan Kajian Islam ini dilakukan dengan 2 tahap uji coba produk. Tahap uji coba produk kelompok kecil yang menggunakan 10 orang 
peserta didik dan tahap uji coba kelompok besar yang menggunakan 30 orang peserta didik. Adapun hasil yang diperoleh dari uji coba kelompok kecil adalah ini berjumlah total 479 dengan skor maksimal 600 dan persentasenya adalah 79,8\% yang memiliki kriteria Baik atau Menarik. Tujuan dilakukan uji coba kelompok kecil ini adalah untuk melihat tanggapan responden peserta didik terhadap e-Modul Bryophyta dengan Kajian Islami yang telah dikembangkan oleh peneliti serta tahap uji coba kelompok kecil ini merupakan tahap awal untuk memperkenalkan e-Modul Bryophyta dengan Kajian Islam ini kepada peserta didik. Setelah dilakukan uji coba kelompok kecil, peneliti kemudian melakukan uji coba kelompok besar dengan responden sebanyak 30 orang peserta didik yang diambil secara acak dari kelas X MIA 1 dan X MIA 2 di Madrasah Aliyah AlJamiyatul Wasliyah Tanjungbalai. Adapun hasil yang diperoleh dari uji coba kelompok besar dengan jumlah responden sebanyak 30 orang peserta didik ini memperoleh skor berjumlah total 1566 dari skor maksimal 1600 dan persentasenya adalah $87 \%$ yang artinya e-Modul Bryophyta dengan Kajian Islami ini memiliki kriteria Sangat Baik atau Sangat Menarik bagi peserta didik untuk digunakan di dalam pembelajaran Biologi.

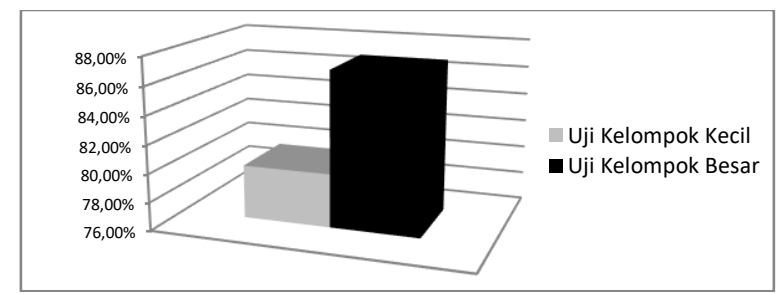

Gambar 2. Hasil Uji Coba Kelompok Kecil dan Uji Coba Kelompok Besar

Selain respon dari peserta didik, pengembangan e-Modul Bryophyta dengan Kajian Islam ini juga dinilai dari penilaian oleh guru biologi. Adapun pada penelitian ini, peneliti meminta 3 orang guru biologi dari 3 sekolah yaitu; SMA Negeri 1 Beringin, Madrasah Aliyah Tahfizil Qur'an Medan dan Madrasah Aliyah Al-Jamiyatul Wasliyah Tanjungbalai untuk menilai e-Modul Bryophyta dengan Kajian Islam yang telah dikembangkan oleh peneliti. Berdasarkan penilaian yang dilakukan 3 orang guru sebagai praktisi, didapatkan hasil persentase rata-rata sebesar 83,5\% dengan kriteria Sangat Layak untuk digunakan didalam pembelajaran Biologi khususnya untuk materi Bryophyta.

Pentingnya e-Modul Bryophyta ini dikembangkan dan menjadi bahan ajar bagi peserta didik, dikarenakan di masa pandemik ini siswa membutuhkan bahan ajar yang dapat membantu mereka untuk memahami pembelajaran secara mandiri dikarenakan kurangnya komunikasi antar pendidik dan peserta didik. Modul pembelajaran yang dikembangkan bernuansa islami sehingga dapat mencapai tujuan madrasah yang tentunya membekali siswa dengan kepribadian islami. Oleh karena itu, materi yang dibawakan oleh e-Modul yang dikembangkan ini menghubungkan materi Bryophyta dengan ayat-ayat Al-Qur'an yang dapat memperdalam dan memperkuat pemahaman peserta didik dari segi ilmu sains nya dan ilmu Islam. Minat dan respon siswa terhadap bahan ajar e-Modul Bryophyta dengan Kajian Islam ini sangat tinggi, dikarenakan eModul Bryophyta dengan Kajian Islam yang dikembangkan ini memiliki animasianimasi dan ikon-ikon yang menarik perhatian siswa untuk membaca e-Modul Bryophyta dengan Kajian Islam. Bahasa yang digunakan e-Modul Bryophyta dengan Kajian Islam ini lebih disederhakan lagi untuk tingkat SMA/MA. 
Sesuai dengan yang diungkapkan oleh Richey dan Klien dalam Novallya, D (2020) bahwa, Modul yang dikembangakan harus memenuhi beberapa komponen dalam pembelajaran yaitu:

1. Mendalami karakter siswa/i

2. Kesesuaian pokok bahasan dengan keadaan dan kebutuhan siswa

3. Penerapan strategi pembelajaran agar kelas aktif

4. Penggunaan media pembelajaran

5. Proses desain bahan ajar yang dikembangkan

Demikian, dapat peneliti simpulkan bahwa e-Modul Bryophyta dengan Kajian Islam untuk siswa/i kelas X MIA tingkat SMA/MA sudah layak digunakan sebagai bahan ajar dan diharapkan dapat menambah pengetahuan dan wawasan siswa/i dalam pokok bahasan Bryophyta. Penggunaan Smartphone sangat bermanfaat dan sangat membantu pada kegiatan belajar online menggunakan e-Modul Bryophyta dengan Kajian Islam yang telah dikembangkan ini.

\section{SIMPULAN}

Berdasarkan hasil penelitian dan pengembangan produk e-Modul Bryophyta dengan Kajian Islam ini maka dapat penulis simpulkan bahwa:

Pengembangan e-Modul Bryophyta dengan Kajian Islam ini menggunakan model Borg \& Gall dengan 7 tahap pengembangan yaitu; tahap yang pertama adalah mencari potensi dan masalah dalam mengembangkan bahan ajar e-Modul Bryophyta dengan Kajian Islam, tahap kedua adalah mengumpulkan data informasi sebagai referensi pengembangan e-Modul, tahap ketiga adalah mendesain produk semenarik mungkin, tahap keempat adalah validasi desain e-Modul dimana pada pengembangan e-Modul Bryophyta dengan Kajian Islami ini di validasikan kepada 1 validator ahli materi, 1 validator ahli media 1 validator ahli Agama Islam, dan 3 orang guru Biologi, selanjutnya tahap kelima adalah revisi desain e-Modul dimana revisi yang didapat dari saran-saran yang diberikan oleh para validator, tahap keenam adalah uji coba produk yang di uji cobakan kepada peserta didik, tahap terakhir adalah revisi produk tahap akhir dimana tahap ini adalah tahap penyempurnaan produk e-Modul Bryophyta dengan Kajian Islam agar produk siap digunakan didalam pembelajaran. Karakteristik modul yang dikembangkan adalah menambahkan nilai-nilai keislamian dalam materi Bryophyta yang menekankan kepada peserta didik untuk belajar materi Bryophyta dengan kajian yang Islami.

Pengembangan e-Modul Bryophyta dengan Kajian Islam ini mendapatkan respon baik oleh para guru Biologi dengan persentase total dari penilaian guru adalah 82,5\% dengan kriteria Sangat Layak dan dari penilaian keseluruhan peserta didik dari uji coba kelompok besar adalah sebesar 79,8 \% dengan kriteria Meranik dan kelompok kecil sebesar $87 \%$ dengan kriteria Sangat Menarik. Dengan demikian modul ini dinyatakan Sangat Layak dan Sangat Menarik digunakan sebagai bahan ajar di era new normal dalam pembelajaran biologi di kelas X Madrasah Aliyah.

\section{DAFTAR RUJUKAN}

Asrul, R. dan Rosnita. (2015). Evaluasi Pembelajaran. Medan: Citapustaka Media.

Buseri, K. (2015). Epistemologi Islam dan Reformasi Wawasan Pendidikan. Jurnal Ilmiah Peuradeun. 3 (1). 
Corrupt Practices Investigation Bureu (CPIB). (2018). Political \& Economic Risk Consultancy (PERC) Limited. https://www.cpib.gov.sg/ (diakses tanggal 26 Juli 2020).

Devie, Dwi, Reny. (2020). Pengembangan e-Modul Biologi Umum Berbasis Konstruktivisme Menggunakan 3D Pageflip. Jurnal Kependidikan Betara. 1 (4). https://doi.org/10.48109/jkb.v1i4.37.

Farida, S. (2016). Hadis-hadis TentangPendidikan. Jurnal Ilmu Hadist. 1(1). https://doi.org/10.15575/diroyah.v1i1.2053.

Hamzah, F. (2015). Studi Pengembangan Modul Pembelajaran IPA Berbasis Integrasi Islam-Sains Pada Pokok Bahasan Sistem Reproduksi Kelas IX Madrasah Tsanawiyah. Jurnal Pendidikan Islam. 1(1):41-54. https://doi.org/10.21070/ja.v1i1.163.

Izaak, W. (2010). Pengembangan Model Modul IPA Berbais Problem Solving Method Berdasarkan Karakteristik Siswa Dalam Pembelajaran Di SMP/Mts. Jurnal FKIP Universitas Pattimura Ambon Cakrawala Pendidikan. 2:178179. https://doi.org/10.21831/cp.v2i2.338.

Lasmiyati. (2014). Pengembangan Modul Pembelajaran untuk Meningkatkan Pemahaman Konsep dan Minat SMP. Jurnal Pendidikan Matematika. 9(2):161174. https://doi.org/10.21831/pg.v9i2.9077.

Lestari dan As'ari. (2013). Pengembangan Modul Pembelajaran Soal Cerita Matematika Kontekstual Berbahasa Inggris untuk Siswa Kelas X. Malang: Universitas Negeri Malang.

Lestari, dkk. (2017). Analisis Pengembangan Bahan Ajar Mikrobiologi Berbasis Inkuiry di IKIP Budi Utomo Malang. Jurnal BIOEDUKASI. 10(2):16. https://doi.org/10.20961/bioedukasi-uns.v10i2.11332.

Mulia, dkk. (2018). Modul Pembelajaran Bernuansa Islami Dengan Pendekatan Inkuiri. Desinal Jurnal. 1(1):1-2.

Sugiyono. (2015). Metode Penelitisan Pendidikan: Pendekatan Kuantitatif, Kualitatif dan $R \& D$. Bandung: Penerbit Alfabeta.

Sugiyono. (2018). Metode Penelitian Kuantitatif, Kualitatif dan $R$ and D. Bandung: Alfabeta.

Satuan Tugas Penanganan Covid19. 2019. Tanya Jawab Covid-19.https://covid19.go.id/ (diakses tanggal 26 Juli 2020). 